\title{
ANALISIS EFEKTIFITAS PENERAPAN SURAT PENAGIHAN PAJAK TERHADAP PENERIMAAN PAJAK PADA KANTOR PELAYANAN PAJAK PRATAMA MEDAN POLONIA
}

\author{
Ester Hervina Sihombing \\ Politeknik Unggul LP3M Medan \\ Jl.Iskandar Muda No.3 EF Medan-Sumatera Utara \\ www.politeknikunggul.ac.id, info@politeknikunggul.ac.id, estersihombing75@yahoo.co.id
}

\begin{abstract}
ABSTRAK
Penelitian ini bertujuan untuk mengetahui bagaimana efektivitas penerapan surat penagihan pajak terhadap penerimaan pajak pada kantor pelayanan pajak pratama medan polonia. Metode penelitian yang digunakan dalam penyusunan skripsi ini adalah metode penelitian deskriptif dengan pendekatan kualitatif. Adapun teknik analisis data dalam penelitian ini adalah peneliti mengkonfirmasi data primer (wawancara dan observasi) dan seluruh data sekunder yang ada dan menyajikannya dengan analisis kualitatif.

Berdasarkan penelitian yang telah dilakukan, efektivitas penerapan surat penagihan pajak terhadap penerimaan pajak pada kantor pelayanan pajak pratama Medan Polonia tersebut ternyata masih belum efektif, baik dari segi kualitas maupun kuantitas. Ini terlihat dari hasil penelitian yang didapat dimana jumlah penagihan surat paksa mengalami peningkatan dari tahun 2012 sebesar 251 surat paksa mengalami kenaikan menjadi 452 surat paksa dan tahun 2014 juga mengalami kenaikan menjadi 664 surat paksa. Secara totalitas terlihat bahwa jumlah kenaikan peningkatan penerimaan pajak lebih sedikit dari kenaikan jumlah WP terdaftar yang terus mengalami penambahan di tiap tahunnya, sementara jumlah penagihan surat teguran dan surat paksa mengalami kenaikan.
\end{abstract}

Kata Kunci : Penerimaan Pajak, Penerapan Surat Penagihan Pajak. 


\section{PENDAHULUAN}

\subsection{Latar Belakang Masalah.}

Untuk mencapai tujuan nasional melalui program-program pembangunan nasional yang telah di susun, pemerintah memerlukan kucuran dana dari masyarakat. Sektor migas yang sebelumnya sangat diandalkan mulai berangsur menurun dan saat ini penerimaan pajak merupakan sektor utama pendanaan Pemerintah sebagai sarana penunjang jalannya roda pemerintahan

Pajak adalah kontribusi wajib negara yang terutang oleh pribadi atau badan yang bersifat memaksa berdasarkan Undang- Undang dengan tidak mendapat imbalan secara langsung dan digunakan untuk keperluan Negara bagi sebesarbesarnya kemakmuran rakyat. Namun, dalam penerapan pembayaran pajak masih banyak dijumpai wajib pajak yang tidak membayar pajak, yang tidak menyetor angsuran dan tunggakan pajak secara tepat waktu. Melihat masih adanya wajib pajak yang tidak ataupun menunggak pembayaran pajak maka pemerintah melaului undang-undang terbaru yaitu UU No.19 tahun 2000 menerbitkan Pengihan Pajak dengan surat paksa sehingga mempunyai kekuatan hukum memaksa untuk penagihan tunggakan pajak adalah Penagihan Pajak dengan Surat Paksa (PPSP).
Menurut UU RI Nomor 19 Tahun 2000 tentang Penagihan Pajak dengan Surat Paksa pasal 1 ayat (12), "Penagihan Pajak dengan Surat Paksa adalah surat perintah membayar utang pajak dan biaya penagihan pajak". Jumlah tagihan pajak yang tidak atau kurang dibayar sampai dengan tanggal jatuh tempo pembayaran sesuai yang tercantum dalam STP, SKPKB, dan SKPKBT ditagih dengan menggunakan Surat Paksa.

Surat Paksa merupakan surat perintah membayar utang pajak dan biaya penagihan pajak. Surat kuasa memiliki kekuatan eksekutorial dan kedudukan hukum yang sama dengan putusan pengadilan yang telah mempunyai kekuatan tetap. Apabila utang pajak tidak dilunasi setelah 21 hari dari tanggal surat teguran maka akan diterbitkan surat paksa yang disampaikan oleh juru sita pajak negara dengan dibebani biaya penagihan, utang pajak harus dilunasi dalam waktu $2 \times 24$ jam.

Penagihan pajak di dalam instansi pemerintahan antara lain adalah untuk menjaga kestabilan pendapat keuangan baik di daerah maupun pusat. Karena pajak merupakan salah satu sumber pendapatan negara. Meningkatkan efisiensi dan efektivitas penagihan pajak sangatlah membutuhkan partisipasi masyarakat secara aktif. Penagihan pajak merupakan serangkaian upaya atau tindakan agar 
penanggung pajak melunasi utang pajak dan biaya penagihan pajak dengan mengatur atau memperingatkan, melaksanakan penagihan seketika dan sekaligus memberitahukan surat paksa, mengusulkan pencegahan, melaksanakan penyitaan, melakukan penyanderaan, menjual barang-barang yang telah disita. Peningkatan jumlah wajib pajak adalah tujuan dari upaya ekstensifikasi. Pemeriksaan dan penagihan pajak adalah upaya intensifikasi penerimaan pajak.

Dalam penyelesaian tunggakan pajak yang terutang dari penunggak pajak di serahkan ke masing-masing wilayah, dikelola oleh Kantor Pelayanan Pajak pada seksi penagihan yang kemudian di laporkan kepada direktorat jenderal Pajak. Pemerintah berharap penerapan penerbitan surat paksa berpengaruhnya terhadap kepatuhan pelunasan utang pajak dan juga diharapkan dapat meningkatkan kepatuhan wajib pajak, jika kepatuhan dan jumlah wajib pajak meningkat maka akan meningkatkan penerimaan pajak tentunya.

Dari uraian diatas maka tampaklah perlunya penerbitan surat paksa di lakukan untuk wajib pajak yang tidak patuh dalam membayar pajaknya. Karena itu menjadi menarik untuk di kaji apakah dengan penerapan surat paksa dapat mempengaruhi kepatuhan dalam pelunasan utang pajak sebagai wajib pajak.

\subsection{Rumusan Masalah}

Berdasarkan latar belakang diatas dapat dirumuskan permasalahan yang akan diselesaikan dalam penelitian ini adalah :

1. Bagaimana efektifitas penerapan surat penagihan pajak terhadap penerimaan pajak pada Kantor Pelayanan Pajak Pratama medan Polonia ?

\subsection{Tujuan Penelitian}

Adapun tujuan atau hasil yang ingin dicapai dalam penelitian ini adalah sebagai berikut :

1. Untuk efektifitas penerapan surat penagihan pajak terhadap penerimaan pajak pada kantor pelayanan pajak pratama medan polonia?

\subsection{Metode Penelitian}

Dalam rangka memperoleh data yang relevan sebagai dasar penyusunan laporan, untuk mengumpulkan data dan mendapatkan informasi yang diperlukan dalam penelitian ini, maka penulis menggunakan metode penelitian sebagai berikut :

1. Pengamatan (Observasi) yaitu penulis mengumpulkan data mencari data secara langsung ke Kantor Pelayanan Pajak (KPP) Pratama Medan Polonia. 
2. Dokumentasi yaitu kegiatan mengumpulkan dan mencari data dengan membuat daftar dokumentasi yang telah diperoleh dari instansi, penulis juga melakukan pengamatan yang dilakukan berdasarkan bahan bacaan, diperpustakan, Keputusan Menteri Keuangan, Keputusan Direktorat Jendral Pajak, surat Peredaran dan sumber lainnnya yang berhubungan dengan masalah yang dihadapi penulis untuk memperoleh data dan keterangan yang dibutuhkan dalam penelitian ini.

\section{TINJAUAN PUSTAKA}

\section{I. Pengertian Penagihan pajak}

Menurut Direktorat Jenderal Pajak (2010: 232) penagihan pajak adalah serangkaian tindakan agar penanggung pajak melunasi utang pajak dan biaya penagihan pajak dengan menegur atau memperingatkan, melaksanakan penagihan seketika dan sekaligus, memberitahukan surat paksa, mengusulkan pencegahan, melaksanakan penyitaan, melaksanakan penyanderaan, menjual barang yang telat disit.

Menurut Priantara (2014: 25) penagihan pajak merupakan suatu tindakan untuk mendapatkan pelunasan atas semua piutang pajak yang harus dibayar oleh wajib pajak atau penanggung pajak baik dengan cara lembut atau persuasif dan administratif hingga cara penyitaan dan pelelangan.

Beberapa alasan yang menyebabkan Surat Tagihan Pajak (STP) dapat diberikan wajib pajak antara lain adalah :

1. Pajak Penghasilan dalam tahun berjalan tidak di bayar atau kurang bayar.

2. Dari hasil penelitian Surat pemberitahuan terdapat adanya kekurangan pembayaran pajak sebagai akibat salah hitung atau salah tulis.

3. Wajib pajak di kenakan sanksi administrasi berupa denda atau bunga.

4. Pengusaha yang dikenakan pajak berdasarkan Undang-Undang pajak pertambahan Nilai 1984 tetapi tidak melaporkan kegiatan usahanya untuk dikukuhkan sebagai pengusaha kena pajak (PKP).

5. Pengusaha yang tidak dikukuhkan sebagai pengusaha kena pajak tetapi membuat faktur pajak atau pengusaha telah dikukuhkan sebagai pengusaha kena pajak tetapi tidak membuat faktur pajak tetapi tidak tepat waktu atau tidak mengisi selengkapnya Faktur Pajak. 
6. Pengusaha Kena Pajak melaporkan faktur pajak tidak sesuai dengan masa penerbitan faktur pajak;

7. Pengusaha Kena Pajak yang gagal berproduksi dan telah diberikan pengembalian Pajak Masukan

\subsection{Tindakan Penagihan Pajak}

Dalam bidang administrasi perpajakan dikenal beberapa bentuk tindakan penagihan yaitu penagihan pasif, penagihan aktif, dan penagihan dengan surat paksa.

a. Penagihan pasif

Penagihan pasif adalah tindakan yang dilakukan oleh Kantor Pelayanan Pajak dengan cara memberikan himbauan kepada Wajib Pajak agar melakukan pembayaran pajak sebelum tanggal jatuh tempo. Penagihan pajak dilakukan dengan menggunakan Surat Tagihan Pajak (STP), SKPKB, SKPKBT, Surat Keputusan Pembetulan, Surat Keputusan Keberatan, Putusan Banding yang menyebabkan jumlah pajak terutang menjadi lebih besar. Penagihan pasif merupakan tugas pengawasan fiskus atau kepatuhan Wajib Pajak dalam melaksanakan kewajibannya sesuai dengan Undang-undang yang berlaku. b. Penagihan aktif

Penagihan aktif adalah penagihan yang didasarkan pada STP, SKPKB, SKPKBT dimana Undang-undang telah menentukan tanggal jatuh tempo pembayaran yaitu 1 bulan terhitung mulai dari STP, SKPKB, SKPKBT diterbitkan. Jika dalam jangka waktu 30 hari utang pajak belum juga dilunasi maka 7 hari setelah tanggal jatuh tempo akan dilakukan tindakan penagihan pajak yang di awali dengan menerbitkan surat teguran dan melaksanakan surat paksa.

Penagihan aktif ini merupakan kelanjutan dari penagihan pasif, dimana dalam upaya penagihan ini fiskus berperan aktif, dalam arti tidak hanya mengirim STP atau SKP tetapi juga akan diikuti dengan tindakan dan dilanjutkan dengan pelaksanaan lelang.

\subsection{Fungsi Surat Tagihan Pajak}

Adapun fungsi Surat Tagihan Pajak adalah sebagai berikut :

1. Sebagai Koreksi atas jumah pajak terutama SPT Wajib Pajak yang artinya jika Wajib Pajak dalam tahun berjalan tidak atau kurang dibayar / disetor ataupun kekurangan pembayaran pajak, 
akibat salah hitung dan salah tulis

dalam surat pemberitahuan.

2. Sarana untuk mengenakan sanksi berupa bunga atau denda.

3. Alat untuk menagih.

\subsection{Surat Paksa}

Menurut Mardiasmo (2013), "Surat Paksa adalah surat perintah membayar utang pajak dan biaya penagihan pajak".

Sebagai surat yang mempunyai kuasa hukum yang pasif, tentu memiliki ciri-ciri dan kriteria tersendiri. Dalam Undangundang No. 19 tahun 2000 sebagai perubahan atas Undang-undang No.19 tahun 1997 Pasal 7 ayat 1 menyebutkan bahwa fisik dari surat paksa sendiri di bagian kepalanya bertuliskan "Demi Keadilan dan Ketuhanan Yang Maha Esa”. Dalam Pasal 7 ayat 2 disebutkan bahwa surat paksa sekurang-kurangnya harus memuat:

1. Nama Wajib Pajak atau nama Wajib Pajak dan Penanggung Pajak,

2. Dasar penagihan,

3. Besarnya utang pajak,

4. Perintah untuk membayar.

\subsection{Penerbitan Surat Paksa}

Menurut pasal 8 Undang-Undang Nomor 19 Tahun 2000 Surat Paksa diterbitkan apabila: a. Penanggung pajak tidak melunasi utang pajak sampai tanggal jatuh tempo pembayaran dan kepadanya telah diterbitkan Surat Teguran atau Surat Peringatan atau surat lain yang sejenis.

b. Terhadap Penaggung Pajak telah dilaksanakan Penagihan Seketika dan Sekaligus.

c. Penanggung Pajak tidak memenuhi ketentuan sebagaimana tercantum dalam keputusan persetujuan angsuran atau penundaan pembayaran pajak. Surat Paksa sekurang-kurangnya memuat :

a. Nama Wajib Pajak, atau Penanggung Pajak

b. Dasar penagihan

c. Besarnya utang pajak

d. Perintah untuk membayar dalam waktu 2x24 jam sejak Surat Paksa disampaikan.

\subsection{Tata Cara Penagihan Pajak} dengan Surat Paksa

Keputusan Menteri Keuangan Republik Indonesia Nomor 561/KMK.04/2000 Tentang Tata cara Pelaksanaan Penagihan Seketika dan Sekaligus dan Pelaksanaan Surat Paksa.

1. Surat diberitahukan oleh Juru Sita Pajak dengan pernyataan dan 
penyerahaan salinan surat paksa

kepada penanggung pajak.

2. Pemberitahuan Surat Paksa Sebagaimana dimaksud dalam ayat (1) dituangkan dalam Berita acara sekurang-kurangnya memuat hari dan tanggal pemberituan surat paksa, nama Juru sita pajak, nama yang menerima, dan tempat pemberitahuan surat paksa.

A. Surat Paksa terhadap orang pribadi diberitahukan oleh Juru sita Pajak kepada :

a. Penanggung pajak ditempat, tempat usaha atau tempat lain yang memungkinkan.

b. Orang dewasa yang bertempat tinggal bersama ataupun yang bekerja ditempat usaha penanggung pajak, apabila penanggung pajak yang bersangkutan idak ditemukan.

c. Salah seorang ahli waris atau pelaksana wasiat, yang menggurus harta penagihan, apabila wajib pajak telah meninggal dunia dan harta waris belum di bagikan.

d. Para ahli waris, apabila wajib pajak meninggal dunia dan harta warisan telah dibagi
B. Surat Paksa terhadap Badan diberitahukan oleh Juru sira pajak kepada

a. Pengurus, kepala perwakilan, kepala cabang, penaggung jawab, pemilik modal baik ditempat kedudukan badan yang bersangkutan, ditempat tinggal mereka maupun ditempat lainnya yang memungkinkan atau

b. Pegawai tetap ditempat kedudukan atau tempat usaha badan yang bersangkutan apabila Jurusita pajak tidak dapat menjumpai salah seorang pengurus, sebagaimana dalam nomor 1 (satu).

\section{HASIL PENELITIAN DAN PEMBAHASAN}

\subsection{Hasil Penelitian}

Untuk mengetahui berapa banyak jumlah wajib pajak yang telah mendaftarkan diri untuk memiliki NPWP pada Kantor Pelayanan Pajak (KPP) Pratama Medan Polonia, pada tabel di bawah ini akan disajikan data jumlah wajib pajak terdaftar di KPP Pratama Medan Polonia 
Tabel 3.1.

Jumlah Wajib Pajak Terdaftar di KPP Pratama Medan Polonia

\begin{tabular}{|l|l|l|}
\hline \multirow{2}{*}{ Tahun } & \multicolumn{2}{|l|}{ JUMLAH WAJIB PAJAK } \\
\cline { 2 - 3 } & Orang Pribadi & Badan \\
\hline 2012 & 4262 & 23947 \\
\hline 2013 & 4419 & 24855 \\
\hline 2014 & 4612 & 26026 \\
\hline
\end{tabular}

Sumber : Data dari Kantor Pelayanan Pajak Pratama Medan Polonia

Data Wajib Pajak atas Ketidakpatuhan dalam memenuhi perpajakannya dapat dilihat dari tabel sebagai berikut :

Tabel 3.2.

\section{Jumlah Penerbitan Surat Teguran Di} KPP Pratama Medan Polonia Tahun 2012, 2013 dan 2014

\begin{tabular}{|l|c|}
\hline Tahun & $\begin{array}{l}\text { Surat Teguran } \\
\text { (Lembar) }\end{array}$ \\
\hline Januari - Desember 2012 & 523 \\
\hline Januari - Desember 2013 & 430 \\
\hline Januari - Desember 2014 & 457 \\
\hline
\end{tabular}

Sumber : Data dari Kantor Pelayanan Pajak Pratama Medan Polonia

Dari tabel di atas dapat dilihat bahwa kinerja aparatur pajak seksi penagihan di KPP Pratama Medan Polonia dalam melaksanakan pajak pada tahun 2012, 2013 dan tahun 2014, ternyata sebagian Wajib Pajak memenuhi kewajiban perpajakannya, dalam hal membayar pajak yang terutang. Hal ini dapat dilihat dari jumlah penerbitan Surat Teguran dari tahun 2012, 2013 dan tahun 2014. Dan masih ada saja Wajib Pajak yang tidak memenuhi kewajibannya membayar pajak, Untuk Wajib Pajak yang tidak memenuhi kewajiban perpajakannya atau menghiraukan pajak maka pihak aparatur pajak akan menerbitkan Surat Paksa sebagai sarana pencairan tunggakan pajak.

Dibawah ini merupakan tabel penerbitan Surat Paksa oleh KPP Pratama Medan Polonia.

Tabel 3.3.

\section{Jumlah Penerbitan Surat Paksa Di KPP} Pratama Medan Polonia

Tahun 2012, 2013 dan Tahun 2014

\begin{tabular}{|l|c|}
\hline Tahun & Surat Paksa (Lembar) \\
\hline Januari - Desember 2012 & 251 \\
\hline Januari - Desember 2013 & 452 \\
\hline Januari - Desember 2014 & 664 \\
\hline
\end{tabular}

Sumber : Data dari Kantor Pelayanan Pajak Pratama Medan Polonia

Dari banyaknya Surat Teguran yang dikeluarkan oleh KPP Pratama Medan Polonia pada tahun 2012 ternyata Wajib Pajak yang segera melunasi atau membayar utang pajaknya meningkat, hal ini dapat dilihat dari jumlah Surat Paksa yang diterbitkan pada tahun 2012 yaitu sebanyak 251 lembar, lebih sedikit dari jumlah Wajib Pajak yang memperoleh Surat Teguran yang dikeluarkan pada tahun 2012 sebanyak 523 lembar oleh KPP Pratama Medan Polonia. Namun pada tahun 2013 ternyata sebagian tingkat kesadaran wajib pajak dalam hal melunasi utang pajak atau membayar pajaknya semakin menurun, 
dapat dilihat dari jumlah surat paksa yang diterbitkan pada tahun 2013 sebanyak 452 . Kemudian pada tahun 2014 sebagian tingkat kesadaran wajib pajak dalam hal melunasi utang pajak atau membayar pajaknya juga semakin menurun, dapat dilihat dari jumlah Surat Paksa yang diterbitkan sebanyak 664 lembar, lebih banyak dari jumlah penerbitan Surat Teguran yang diterbitkan pada tahun 2014 sebanyak 457 lembar, berarti jumlah surat tagihan yang dihiraukan atau tidak dipenuhi sebanyak 207 lembar. Maka dari itu dapat kita lihat tingkat kesadaran wajib pajak semakin menurun dibandingkan tahun sebelumnya.

Tabel 3.4.

Jumlah Penerimaan Pajak di KPP Pratama Medan Polonia tahun 2012, 2013 dan Tahun 2014

\begin{tabular}{|c|c|c|c|}
\hline \multicolumn{4}{|c|}{$\begin{array}{c}\text { Penerimaan Pajak di Kantor Pelayanan Pajak (KPP) } \\
\text { Pratama Medan Polonia }\end{array}$} \\
\hline Keterangan & \multicolumn{3}{|c|}{ Penerimaan Pajak Bagi Wajib Pajak Pribadi } \\
\hline Tahun & 2012 & 2013 & 2014 \\
\hline $\begin{array}{c}\text { Penerimaan } \\
\text { Pajak }\end{array}$ & $\begin{array}{c}\mathrm{Rp} \\
10.015 .600 .243\end{array}$ & $\begin{array}{c}\mathrm{Rp} \\
11.029 .162 .493\end{array}$ & $\begin{array}{c}\mathrm{Rp} \\
12.500 .539 .772\end{array}$ \\
\hline
\end{tabular}

Sumber : Data dari Kantor Pelayanan Pajak Pratama Medan Polonia

Dari tabel diatas, dapat kita amati bahwa penerimaan pajak di Kantor Pelayanan Pajak (KPP) Pratama Medan tahun 2012 adalah sebesar Rp. 978.601.956,- peningkatan dari tahun 2012 ke tahun 2013 adalah sebesar Rp. 1.013.562.250,- dan peningkatan dari tahun
2013 ke tahun 2014 adalah sebesar Rp.1.471.377.284,-.

\subsection{Pembahasan Penelitian.}

Jumlah Penagihan Pajak melalui surat teguran pada tahun 2012 ke 2013 mengalami penurunan dari 523 menjadi 430 surat, tahun 2013 ke 204 mengalami kenaikan dari 430 sampai 457. Sementara itu surat paksa dari tahun 2012 sampai tahun 2014 terus mengalami kenaikan yaitu tahun 2012 ada 251 surat paksa, tahun 2013 terdapat 452 surat paksa dan tahun 2014 berjumlah 664 surat paksa. Hal ini menandakan bahwa tingkat kesadaran wajib pajak masih rendah.

Jumlah penerimaan pajak di Kantor Pelayanan Pajak Pratama Medan Polonia dari mengalami kenaikan, tahun 2012 berjumlah Rp.10.015.600.243, tahun 2013 berjumlah Rp. 11.029.162.493, tahun 2014 berjumlah Rp. 12.500.539.772. Terlihat bahwa kenaikan jumlah kenaikan penerimaan pajak masih relatif kecil dibanding dengan kenaikan jumlah WP terdaftar yang terus mengalami penambahan di tiap tahunnya, dimana tahun 2012 berjumlah 4262 untuk wajib pajak pribadi dan 23947 dari WP Badan 23947. tahun 2013 berjumlah 4419 untuk wajib pajak pribadi dan 23947 dari Badan 24855 tahun 2014 berjumlah 4612 untuk wajib pajak pribadi dan 26026 dari WP Badan 23947. Jumlah surat penagihan melalui 
surat teguran dan surat paksa tahun 2012 berjumlah 523 dan 251. Tahun 2013 berjumlah 430 dan 452. Tahun 2014 berjumlah 457 dan 664 . Ini berarti bahwa efektifitas penerapan surat penagihan Pajak terhadap penerimaan pajak kantor pelayanan pajak Pratama Medan Polonia belum efektif secara maksimal.

\section{KESIMPULAN DAN SARAN}

\subsection{Kesimpulan}

1. Jumlah penerimaan pajak dari tahun 2012 - 2014 mengalami peningkatan di Kantor Pelayanan Pajak Pratama Medan Polonia. Pada dasarnya peningkatan Wajib Pajak melalui surat penagihan pajak tidak terlalu berpengaruh pada peningkatan pajak di Kantor Pelayanan Pajak Pratama Medan Polonia. Terlihat dari jumlah kenaikan peningkatan penerimaan pajak lebih sedikit dari kenaikan jumlah WP terdaftar yang terus mengalami penambahan di tiap tahunnya, sementara jumlah penagihan surat teguran dan surat paksa mengalami kenaikan. Ini berarti bahwa efektifitas penerapan surat penagihan Pajak terhadap penerimaan pajak kantor pelayanan pajak Pratama Medan Polonia belum efektif secara maksimal.

\subsection{Saran}

1. Diharapkan kepada pemerintah dan instansi yang terkait agar bekerja sama dengan baik, sehingga pelaksanaan penagihan pajak dapat berjalan atau dapat dilaksanakan dengan sebaikbaiknya. Hal ini bertujuan untuk menghindari tunggakan pajak yang dilakukan oleh Wajib Pajak. Untuk itu perlu peningkatan fungsi pengawasan terhadap penagihan pajak dan koordinasi serta kerja sama dalam pelaksanaan tugas pada Kantor Pelayanan Pajak Medan Polonia untuk meningkatkan penerimaan pajak lebih efisien.

\section{DAFTAR PUSTAKA}

Adrian Sutedi, 2014, perpajakan Indonesia, indeks, Jakarta

Early Suandi, 2014, Perpajakan, Indeks, Yogyakarta

Siti Resmi, 2016, Perpajakan Teori dan Kasus, edisi 9 ,Salempa Empat, Yogyakarta

Soeparman Soemohamijaya, 2013, Perpajakan, Andi, Yogyakarta

Undang-Undang Republik Indonesia Nomor 28 Tahun 2007 Tentang Perubahan Perpajakan

Undang-Undang Nomor 28 Tahun 2007 Tentang Ketentuan Umum dan Tata Cara Perpajakan 
